\title{
СОЦИАЛЬНОЕ ПОЛОЖЕНИЕ СЕЛЬСКОГО НАСЕЛЕНИЯ КАРАКАЛПАКСТАНА В ПОСЛЕВОЕННЫЙ ПЕРИОД
}

\author{
Мадреймов Е. \\ Академический лицей Нукусского филиала \\ Ташкентского Государственного Аграрного Университета
}

DOI: https://doi.org/10.31435/rsglobal_ijitss/30112019/6822

\section{ARTICLE INFO}

Received 25 September 2019

Accepted 18 November 2019

Published 30 November 2019

\section{KEYWORDS}

rural population, infrastructure, administration, living and working conditions, food, consumption of goods, violation of the Charter, migration.

\begin{abstract}
The article examines some aspects of the social situation of dehkans in the postwar period in Karakalpakstan. During this period, the state takes a number of decisions to increase cotton crops at the expense of grain crops and reduce the homesteads of the rural population. The main source of income of collective farmers was a subsidiary farm, where the main food products were grown. Decline in prices for a number of food and non-food products during 1947-1950. However, food was still unavailable to most, often the shelves of aul shops were empty: some were sold, some were distributed among the executives. Strict control and administration, unfair distribution of goods of mass consumption has led to economic sabotage and migration of the rural population. Collective farmers often opposed administration, but mostly preferred hidden, latent forms of struggle for their own interests, avoiding direct confrontation with the leadership of the collective farm.
\end{abstract}

Citation: Мадреймов Е. (2019) Social'noe Polozhenie Sel'skogo Naseleniya Karakalpakstana v Poslevoennyj Period. International Journal of Innovative Technologies in Social Science. 8(20). doi: 10.31435/rsglobal_ijitss/30112019/6822

Copyright: (C) 2019 Мадреймов Е. This is an open-access article distributed under the terms of the Creative Commons Attribution License (CC BY). The use, distribution or reproduction in other forums is permitted, provided the original author(s) or licensor are credited and that the original publication in this journal is cited, in accordance with accepted academic practice. No use, distribution or reproduction is permitted which does not comply with these terms.

Введение. История послевоенного периода Каракалпакстана на современном этапе насыщена противоречивыми характеристиками. В его изучении в советский период историографии важное место отводилось освещению политико-экономических и культурных доминантов, ведущей роли партий и советов. Однако, «исследователи упускали роль человеческого фактора в общественном развитии, ценностных, нормативных, мотивационных ориентаций человека в общественном устройстве, факторы и условия, определяющие население по демографической и социально-экономической характеристике» [1].

Цель исследования. В данном контексте послевоенное время идеально подходит для раскрытия человеческого фактора в истории. Послевоенное время в истории Каракалпакстана было периодом сложных социально-экономических и демографических изменений. Сельское хозяйство в Каракалпакстане занимало основное место в экономике республики, основное производство сосредотачивалось в колхозах, где преобладал ручной труд, а основной тягловой силой оставались крупнорогатый скот, лошади, и ишаки. Почти бесплатный труд бесправных колхозников, которые не имели возможности выйти их колхоза, переменить место жительства и не имели гарантий социального обеспечения, при сильной системе администрирования позволял в какое-то время обеспечивать государство необходимым сельскохозяйственным сырьем и другой продукцией. Хотя по итогам 1945 года многие хозяйства так и не выполнили план хлопкозаготовок и оказались в огромном убытке.

В 1946 году был принят ряд постановлений по развитию хлопководства, они получили отражение в Законе «О пятилетнем плане восстановления и развития народного хозяйства 
Каракалпакской АССР на 1946-1950 гг.» [2]. А 2 февраля 1946 года было принято постановление СНК СССР «О плане и мероприятиях по восстановлению и дальнейшему подъему хлопководства в Узбекистане на период 1946-1953 гг.» [3], где предусматривалось увеличение посевов хлопка и люцерны в Узбекистане на 15\%. В частности, предусматривалось повышение урожайности хлопка до 12 центнеров, почти вдвое увеличить посевы люцерны, увеличить поголовье крупнорогатого скота почти в 3,5 тысяч. В Каракалпакстане удельный вес посевов хлопка увеличивалось за счет сокращения посевных площадей под зерновыми культурами - пшеницы, джугары, ячменя.

Однако колхозы Каракалпакстана из года в год не выполняли государственные планы по хлопководству, получал крайне низкие урожаи хлопка-сырца. Вследствие этого колхозные хозяйства оставались слабыми в экономическом отношении, не могли оплатить сельхозналог и впоследствии оставались в долгу перед государством. Так в 1952 г. задолженность нескольких колхозов республики составили 82 млн. руб. [4].

Результаты исследования. Условия жизни сельского населения Каракалпакстана, которых насчитывалось около 400 тыс. человек, были тяжелыми. Сельские жители в основном работали в колхозах, однако на них не распространялось государственное пенсионное обеспечение, а также выплаты и льготы. С 1939 года существовал обязательный минимум выработки трудодней для трудоспособных работников. Нагрузка на одного трудоспособного работника в колхозах была огромной. Например, в Тахтакупырском районе в 1951 г. приходилось 2,2 гектара, а уже в 1955 году - 3,7 га, а по всем видам сельхоз культур 3,8 га. Средняя стоимость трудодня в натуральном выражении за 1951-1955 годы составлял от 1,3 кг - 1,6 кг зерна, в денежном выражении эта стоимость составляла: в 1951 г. - 0,26 коп.; в 1952 г. - 0,41 коп., а в 1955 г. на один трудодень выдавалось уже 4 руб. 82 коп., в 1958 г. - 15 руб. 70 коп. Один трудоспособный человек вырабатывал в год 300-350 трудодней [5]. В случае невыполнения этого минимума колхозник мог лишиться приусадебного участка или привлечен к уголовной ответственности. Это привело к незаинтересованности колхозников в результатах своего труда. Прожиточный минимум был очень низок и работники не имели никакого стимула для работы.

Нарушения в нормировании труда, неправильное начисление и несвоевременные выплаты заработной платы и натуральных авансов вызывали недовольство и протест со стороны колхозников. Также имело место незаконная выдача заработной платы лицам, не работающим в колхозе и не имеющим ни одного трудодня. В числе таких лиц были родственники председателя колхоза, аульного совета, секретаря партийной организации и т.д. Например, республиканская газеты «Қызыл Қарақалпақстан» писала о нарушениях в системе распределения товаров колхозникам: «В 9-м ауле колхоза им. Буденного Кунградского района, выданная на оплату трудодней колхозников 4180 кг пшеницы, исчезли без следа. Также из 359 м ткани распределены между колхозниками лишь 191 м, остальная часть члены администрации колхоза поделили меж собой» [6]. Также в некоторых районах наблюдалась ситуация, когда авансы работников колхоза выдавались в сберкассу и руководитель колхоза мог распоряжаться ими по своему усмотрению, не выдавая их работникам [7]. Вследствие такого положения падала трудовая дисциплина, все меньше людей выходили на общественную работу, а некоторая часть недовольных колхозников были вынуждены уходить в другие районы. На основании указа Президиума Верховного Совета СССР от 2 июня 1948 г. «О выселении в отдаленные районы лиц, злостно уклоняющихся от трудовой деятельности и ведущих антиобщественный, паразитический образ жизни», в 1948-1949 годы из Каракалпакстана в отдаленные районы СССР были переселены 89 человек [8]. Граждан выселяли по приговору общего собрания колхоза и по решению райисполкома на 8 лет. Обвиненные в тунеядстве граждане могли обратиться с кассационной жалобой только после пяти лет выселения и имели право возвратиться на родину при ходатайстве районного исполнительного комитета. По архивным материалам видно, что значительная часть кассационных жалоб выселенных колхозников получала отрицательный ответ и они были вынуждены проводить в ссылке все 8 лет. Высланные граждане работали на рудниках, лесозаготовках Хабаровского, Красноярского краев, Иркутской, Кемеровской области, Бурят-Монголии и т.д. Со слов информатора Абдираманова А., 72 л., Шуманайский район, пос. Дехканабад, Максым аул: «Я помню, что в те годы был выслан двоюродный брат отца. О его дальнейшей судьбе нам до сих пор не известно». Другой информатор из Чимбайского района, пос. Тазкара, аул Аралбай, Абдреимов 
Зераб, 89 лет. По его словам, из аула в ссылку были отправлены два колхозника, оба вернулись, один из них возвратился из ссылки с русской женой. Информатор, вспоминая 50 -е годы, подчеркнул, что работа в колхозе была настолько тяжелой, что времени на свой огород не хватало. Он также вспоминал, что один из вернувшихся из ссылки говорил, «работать там (на ссылке) было легче, чем на родине в колхозе». Респондент подчеркивал, что «тяжело было, во время посева хлопка, когда надо было поливать, полоть и, особенно, в самом конце сбора хлопка, когда хлопка на полях уже мало, заставляли собирать курак (гурек). Приходилось по ночам дома выбирать из зеленого курака хлопок. Не разрешалось спать, все время приходили проверять, даже ночью заглядывали в окна, работаем мы или спим» [9].

В структуре питания доминирующее положение занимали мука и овощи, выращенные в приусадебном участке. На колхозников не распространялись продовольственные карточки, гарантировавшие хотя бы минимум важных продуктов питания. Основным источником доходов в традиционном обществе было личное подсобное хозяйство, которое играло значительную роль в формировании сельской семьи. Нормы приусадебных участков до 1950 г. были определены на поливных полях в пределах от 0,15 до 0,25 га, а с января 1950 г. было проведено сокращение размеров приусадебных земель и поголовья скота. Размеры приусадебных участков были урезаны до 0,12-0,15 га. Отрезанные от дехканских хозяйств поливные земли, сады, виноградники, а также скот были переданы колхозам. В ходе этого в республике государство изъяло у сельчан 2622 га земли, а также 1083 голов крупного рогатого скота, 4146 голов мелкого, 180 лошадей [10]. Возврат земель колхозниками ухудшил и без того тяжелое положение, связанное с питанием. Обычно в условиях аула и кишлака жители сеяли зернозлаки - пшеницу, просо, джугары, маш, рис, из овощей традиционно выращивали тыкву, морковь, лук, картошку, дыню, арбуз, а также виноград. Хозяйства, содержавшие скот и домашнюю птицу, имели свое молоко и мясо. В повседневной жизни пища дехкан была простой: загара (лепешки из джугары), гоже (каша из риса с кефиром), вареная тыква, гуртик (клецки из муки) и др. Мясо потребляли мало, в лучшем случае резали домашнюю птицу или козу. В магазине СельПО покупали сахар, чай, мыло, однако, как утверждается в архивных и газетных материалах, был постоянный дефицит этих товаров из-за сокрытия ответственными лицами.

Индивидуальные хозяйства дехкан основывались на ручном труде - кетмень, лопата, пахали тягловым методом. Многочисленные члены семьи, начиная от старших до младшего, работали на участке. Детские руки также находили свое применение в личном подсобном хозяйстве: работа на поле, присмотр за младшими детьми, выпас скота, подготовка топлива, уборка в доме и мн. др. Однако роль подсобного хозяйства в послевоенные годы постепенно снижалась изза усиления зависимости от общественного труда. Часть продукции личных хозяйств сдавалась государству в обязательном порядке: мясо, овощи, зерно, молоко, шерсть, пушнина. Хотя это считалось делом добровольным, но по негласному распоряжению властей, каждый колхоз должен был сдать государству вышеперечисленное сырье. От поставок были освобождены лишь семьи погибших и пропавших без вести в годы войны, инвалиды войны, военнослужащих. Семья учителя освобождалась, только в том случае если он был главой семьи. Если же учителем был член семьи (жена, сын и т.д.), домохозяйство привлекалось к поставкам на 50\%.

В последующие годы государство приняло ряд решений, которые непосредственно касалось населения. В 1946-1950 гг. было проведено трехкратное снижение государственных розничных цен на товары массового потребления. Со 2 июля 1946 года были снижены цены на ряд промышленных товаров, таких как обувь (на 42\%), галоши (на 57\%), трикотаж (на 30\%), мыло (46\%), алюминиевую посуду (на 54\%) и т.д. В 1947 году была проведена денежная реформа, отменены продовольственные карточки. Были установлены государственные цены на основные продовольственные товары, например, 1-й сорт пшеничной муки стоил в среднем 8 руб., кусковой сахар - 15 руб., литр молока - 3-4 руб., 100 грамм байхового чая (1-й сорт) - 16 руб. В среднем цены были снижены на 17\%. С конца 1947 года по 1949 годы цены снизились еще на 14\% в среднем. С 1 марта 1950 года цены были снижены еще на $20 \%$ (по сравнению с 1949 годом) и по сравнению с ценами декабря 1947 года цены были снижены в среднем на 43\%.

Снижение цен на продукты проводились в ущерб сельскому хозяйству. Оно было направлено, прежде всего, на обеспечение городов. Например, в городах цены были чуть ниже, чем в сельской местности, цены на непродовольственные товары также различались. Так, сатиновая ткань в городах продавалась по 25 руб. 20 коп., а в сельской местности - 28 руб. 00 коп., мужские 
ботинки - 260 и 288 руб. соответственно. Самым дорогим товаром из одежды были женские туфли: в городах продавали их по 260 руб., а в аулах и кишлаках - по 288 руб. Если учесть, что даже в 1951 году один трудодень колхозника, как указывалось выше, составлял 0,26 копеек, в месяц приблизительно 7-8 руб., а в год - около 90 руб., то для приобретения даже мужских ботинок колхознику необходимо было копить заработанные деньги в течение 3-4 лет.

Тяжелые условия быта и труда, низкий уровень социальной сферы, ограничение приусадебных хозяйств сопровождалось обострением демографической ситуации на селе. В начале 1950-х годов в Каракалпакстане в колхозах насчитывалось 42579 хозяйств, из которых 31615 проживали в хуторах, 10654 хозяйства проживали в кишлаках и поселках. Некоторая часть сельского населения, недовольная тяжелым материальным положением, уходила в другие колхозы и районы. За 2-3 года откочевало из колхозов 1895 хозяйств и в пределах одного района поселилось 846 хозяйств, в колхозах других районов 579 хозяйств; выбыло за пределы республики 225 хозяйств; и трудоспособные члены из оставшихся 245-ти хозяйств работали вне колхозов [11].

Заключение. Как видим, социальное положение сельского населения Каракалпакстана в послевоенный период оставалась тяжелой. Государство увеличило посевы хлопка за счет сокращения посевов зерновых культур, также были сокращены приусадебные участки колхозников, которые являлись основным источником доходов. Под лозунгом восстановления и интенсификация сельскохозяйственного производства шла мобилизация всех трудовых ресурсов внеэкономическими, директивными методами, носившими жесткий, полувоенный характер. Колхозники часто выступали против администрирования, но в основном предпочитали скрытые, латентные формы борьбы за собственные интересы, избегая прямой конфронтации с руководством колхоза. Самыми распространенными из них и наиболее значимыми по последствиям были переезд в другое местожительство (часто в города) и экономический саботаж. Это наносило ощутимый ущерб колхозному производству и не ухудшало и без того тяжелое социальное положение самих дехкан.

\section{ЛИТЕРАТУРА}

1. Нуржанов С., Дошниязов Ж. Социально-духовное состояние общества Каракалпакстана в 1960-1980-е годы.// Вестник Каракалпакского отделения Академии наук Республики Узбекистан. 2011. №4.

2. Закон «О пятилетнем плане восстановления и развития народного хозяйства Каракалпакской АССР на 1946-1950 гг.». - Н., 1946. - С. 5.

3. Каракалпакстан жана тарийхы. - Н., 2003. - С. 285.

4. Ц ЦГА РК, ф.1, оп.8, д.430, л.9; ф. Р-322, оп.1, д.1994, л.16.

5. ЦГА РК, ф. Р-322, оп.1, д.1995, л.5.

6. Кызыл Каракалпакстан, 1946, 15 июль.

7. ЦГА РК, ф. Р-322, оп.1, д.1693, л.68, л.98; ф.1, оп.9, д.256, л.62.

8. ЦГА РК, ф. Р-229, оп.1, д.898, л.1.

9. Полевые записи автора за 2019 год.

10. История Каракалпакской АССР. Том второй. - Т., 1974. - С. 275.

11. ЦГА РК, ф.1.оп.6, д.756, л.129. 